\title{
Help or hindrance: the relationship of physical activity with aggressiveness and self-esteem in 16-year-old adolescents
}

\begin{abstract}
BACKGROUND
Puberty is a particularly important period for moulding one's lifestyle. Physical activity (PA) levels exhibited by teenagers remain low despite efforts to promote it, and the percentage of individuals who are exempt from taking part in physical education classes is high. In this context, the aim of the current study is to analyse the levels of aggression and self-esteem in adolescents characterised by different levels of physical activity.
\end{abstract}

\section{PARTICIPANTS AND PROCEDURE}

A total of 968 16-year-old adolescents took part in the study. Participants were divided into four subgroups: 1) a nonactive group, $n=141$ (95 girls); 2) a physical education (PE) group, $n=514$ (322 girls); 3) a high PA group, $n=178$ (81 girls); and 4) an athlete group, $n=135$ (66 girls). Participants were asked to complete a socio-demographic survey and a set of questionnaires (IPAO, KAM-RE, and SES).

\section{RESULTS}

The non-active group scored higher than the PE and high PA groups on the general aggressiveness scale. Statistically significant differences were found between the non-active group and other groups for direct and indirect aggression, opposition, and verbal aggression. The athlete group scored higher on the indirect aggression scale than the PE group. The high PA group scored higher than the non-active group in self-esteem.

\section{CONCLUSIONS}

Undertaking compulsory physical activity in school and additional physical activity based on one's own interests is associated with lower levels of aggression in comparison to individuals who do not undertake any physical activity. For this reason, it is necessary to continue consistently promoting physical activity in school and during free time.

\section{KEY WORDS}

adolescence; physical activity; individual differences; physical education

ORganization - 1: Department of Health Psychology, Gdansk University of Physical Education and Sport, Gdansk,

Poland · 2: Institute of Psychology, University of Gdansk, Gdansk, Poland

AUthors' Contributions - A: Study design - B: Data collection - C: Statistical analysis · D: Data interpretation .

E: Manuscript preparation · F: Literature search · G: Funds collection

CORRESPONding AUthor - Magdalena Jochimek, Ph.D., Gdansk University of Physical Education and Sport, 1 Kazimierza

Górskiego Str., 80-336 Gdansk, Poland, e-mail: magdalena.jochimek@awf.gda.pl

TO CITE THIS ARTICLE - Jochimek, M., \& Łada, A. B. (2019). Help or hindrance: the relationship of physical activity with

aggressiveness and self-esteem in 16-year-old adolescents. Health Psychology Report, 7(3), 242-253. https://doi.

org/10.5114/hpr.2019.86698

RECEIVED 25.04.2019 • REVIEWED 26.06.2019 • ACCEPTED 26.06.2019 • PUBLISHED 17.07.2019 


\section{BACKGROUND}

\section{PUBERTY AND AGGRESSION AND SELF-ESTEEM}

Forming one's identity is a key process in adolescence. It is associated with the integration of the biological, cognitive, emotional, and social domains (Brinthaupt \& Lipka, 2002; Erikson, 1968). Thus, the development of individuality takes place in both the intrapsychological and interpersonal dimensions (Collins \& Steinberg, 2006).

The first aspect of identity formation is biological puberty, which is associated with the acceptance of one's developing body and sexuality, stabilisation of emotions and basic beliefs, hierarchy of values and needs, and choice of life goals - the assessment of who am I? (Arnold, 2017). Emotional lability accompanies adolescents up until the age of about $16-17$, which is why adolescents often express anger, frequently in the form of defiance towards their significant others (Lippold, Hussong, Fosco, \& Ram, 2018). The change in an adolescent's social role is associated with an increase of tensions in their relationships, especially the relationship between an adolescent and their parents. The influence of hormones is a factor which may exacerbate the conflicts. Increased levels of oestradiol secretion in girls in the initial phase of puberty causes an increase in their aggressiveness and difficulties in controlling their own behaviour (Graber, BrooksGunn, \& Warren, 2006). Increased testosterone levels in boys potentiates their externalising behaviours, a tendency which is especially strong if they have self-regulatory deficits (i.e., low conscientiousness and agreeableness; Reardon, Herzhoff, \& Tackett, 2016). Thus, even if not all adolescents exhibit reactive aggressive behaviours, it is a developmental period in which aggressive behaviours in response to provocation, frustration, or threat are at their peak levels (Lickley \& Sebastian, 2018).

The second dimension in identity formation refers to social identity (Ragelienè, 2016), that is defining the group an adolescent identifies with and belongs to (Brown, 2004). Functioning in the two most important environments - peers and family - is key in the context of development of one's self-esteem (Harter, 2012). Self-esteem is an evaluative - positive or negative - attitude towards one's own self, a kind of global assessment of oneself (Rosenberg, 1979). An important dimension of the global levels of selfesteem is the self-esteem regarding one's physicality (Hagger, Biddle, \& Wang, 2005). Additionally, a teenager has the skills to describe themselves in terms of psychological categories concerning interpersonal relations, emotions, or beliefs (Petersen \& Leffert, 1995). An adolescent's awareness with regards to being accepted by their peers and significant adults is important in the context of self-esteem. For this reason, when engaging with issues regarding adoles- cents' development of self-esteem, one should take into account the broader context of their functioning and the environment they live in by, for example, analysing coexisting internalising or aggressive behaviours and reinforcing school attendance and accomplishments (Smokowski et al., 2016). Faced with the threat of failing at school, a teenager may often take a passive, apathetic, or overly aggressive attitude (Simpson, Peterson, \& Smith, 2010). Social self-esteem is a mediator of the relationship between malevolent aggression and school achievements (Soomro \& Clarbour, 2012). This is why development of self-esteem is a factor that may protect one from experiencing a downward spiral which often triggers aggressive behaviours in response to school failures.

\section{FREE TIME AND SPENDING TIME IN A PEER GROUP - AN OPPORTUNITY OR THREAT?}

Interactions with peers are an opportunity for adolescents to form friendships and intimate relationships, which can be both an opportunity and a risk for a teenager's development. On one hand, adolescents who have opportunities to form positive relationships with their peers assess their health and well being as better (Moreno et al., 2009) and report fewer complaints of a psychological character (Zambon et al., 2010). On the other hand, especially in the case of non-organised groups, there is a higher probability of co-participation in behaviours that are against social norms. Research shows that the frequency of spending evenings with peers is related to the use of marijuana (Kuntsche et al., 2009). Peers make teenagers try cigarettes (Simons-Morton \& Farhat, 2010) and alcohol (Osgood et al., 2013). Peer pressure causes teenagers to exhibit higher levels of externalising behaviours and engage in risky sexual behaviours (Allen, Porter, \& McFarland, 2006). Research on a representative group of teenagers found that the selected groups of friends were uniform in terms of school results, presented social behaviours, and sense of psychological closeness and structure (Cook, Deng, \& Morgano, 2007). Because of this, the peer group with which a teenager spends time should be curated in some way, because friendships and behaviour may depend on the types of activities one engages in.

An important source of support for teenagers is a wide variety of ways to spend free time and organised forms of education where teenagers have the opportunity to form positive relationships not only with their peers, but also with significant adults (Jones \& Deutsch, 2012). Various forms of volunteer work are a great form of mobilisation and source of sensitivity in adolescents, by making them work for their environment - the prosocial behaviours of a peer group encourage this type of behaviour in
Physical activity and individual differences 
teenagers (Farrell, Thompson, \& Mehari, 2018), as do extracurricular art classes (Ersing, 2009) and taking part in organised physical activity (Larson, Hansen, \& Moneta, 2006).

\section{RESEARCH FRAMEWORK - ADOLESCENTS' PHYSICAL ACTIVITY IN RELATION TO AGGRESSIVENESS AND SELF-ESTEEM}

Magdalena Jochimek, Ariadna Beata Łada
It is important to note that physical activity level is connected with psychological variables and that over half of the Polish 15-year-old population is reported to have an insufficient level of physical activity (Kołoło, Guszkowska, Mazur, \& Dzielska, 2018). The positive effects of physical activity can be analysed in the context of both physical health and mental health. Playing sports can improve cognitive functions associated with learning (Chen, 2012; Stroth, Hille, Spitzer, \& Reinhardt, 2009) and school achievements (Howie \& Pate, 2012). Research shows that any physical activity (regular/irregular, high or low intensity, independently of its form) brings health benefits (Poitras et al., 2016)

Puberty is important for shaping one's lifestyle because this is when health behaviours developed in the socialisation process are consolidated. Among the factors that significantly influence health in adulthood are behaviours leading to harm occurring in early and late adolescence: violence and aggressive behaviours, tobacco use, alcohol consumption and substance use, risky sexual behaviours, unhealthy diet, and low levels of physical activity (Kann et al., 2016). In line with WHO guidelines, children and adolescents (up to 18 years old) should take part in physical activity for a minimum of 60 minutes a day (Start Active Stay Active, 2011). This activity should increase heart rate and lung activity, which indicates that it meets the condition to be considered moderate to vigorous physical activity. Exercises engaging large muscle groups are in this category. They are recommended as a part of sports, recreation, performed duties, transport, work, school physical activity classes, and planned exercises. Aerobic activities include jogging, basketball, football, swimming, and skiing. Research shows that, taking the recommended 60 minutes a day as a reference point, $92.50 \%$ of girls and $77.20 \%$ of boys aged 14 to 18 in Poland have low levels of physical activity (Tabak, Mazur, \& Nałęcz, 2017). These indices are still not satisfactory, and continuing health-promotion activities in this area is necessary in Poland and elsewhere (Carson, Staiano, \& Katzmarzyk, 2015), because despite efforts to promote physical activity (McMullen, Ni Chróinín, Tammelin, Pogorzelska, \& van der Mars, 2015) the number of doctor's notes exempting students from partaking in physical activity classes is still increasing (Woynarowska, Mazur, \& Oblacińska, 2015).
A positive relationship is observed between emotion regulation and levels of physical activity (Isasi, Ostrovsky, \& Wills, 2013); this effect is especially visible in the case of negative emotions and aerobic exercises (Bernstein \& McNally, 2017). Interestingly, in the case of adolescents, higher levels of physical activity seem to reinforce the experienced negative emotions in case of peer rejection and make the reduction of negative emotions more flexible in the case of peer acceptance (Shields, Matt, \& Coifman, 2016). Research shows that partaking in physical education at school and extracurricular physical activity classes may foster the development of self-regulation and control over aggressive behaviours (Costin \& Jones, 1992). Other research shows that physical education classes in school do not influence aggressive behaviours in teenagers, and extracurricular physical activity lowers levels of aggression, especially in girls (Park, Chiu, \& Won, 2017). Moreover, interventions increasing physical activity do not directly influence levels of aggression - recreational screen time is the mediator of this relationship, and this is particularly the case for boys (Wade, Smith, Duncan, \& Lubans, 2018). It seems important to bring attention to the forms of physical activity that are undertaken in physical education classes - one study found that engaging in play fighting lowered levels of aggressiveness in teenagers in comparison with the control group who played volleyball (Carraro, Gobbi, \& Moè, 2014).

Playing sports is an important basis for self-esteem (Budnik \& Kaźmierczak, 2008): it increases the positive attitude towards one's physicality (appearance and sense of competence), which leads to an overall increase in self-esteem (Bowker, 2006; Guszkowska, Kuk, Zagórska, \& Skwarek, 2015). Research done with a group of highly qualified athletes, as well as those with smaller successes, showed that there is a positive relationship between self-esteem and sport achievements (Owczarek, 2009). Similar results were found in another study where athletes of the Plus Women's League (the top volleyball league in Poland) were characterised by higher global levels of self-esteem in comparison to players in lower leagues (Bernacka \& Tokarz, 2012). It should be mentioned that the duration of engagement in organised and intensive physical activity indirectly influences the increase in self-esteem, and support from adults mediates this relationship (Oosterhoff, Kaplow, WrayLake, \& Gallagher, 2017). Research also shows that taking part in vigorous physical activity more than 4 times a week is associated with a lower level of selfesteem, so the intensity of physical activity is a factor which protects against low self-esteem (Hrafnkelsdottir et al., 2018).

Summarizing the above, as the results of previous studies are inconclusive, there is a need for further exploration of the role of physical activity in the context of aggressive behaviours. It is also important 
to analyse the role of self-esteem in the context of physical activity of teenagers. Research focused on the relationship between self-esteem and aggressiveness presents contradictory results: some studies find a connection between low self-esteem and aggression (Boden, Fergusson, \& Horwood, 2007; Walker \& Bright, 2009) while others link high self-esteem to aggressive behaviour (Bushman et al., 2009). As mentioned earlier, research concerning self-esteem as a mediator of aggressive behaviour and school achievement has also been conducted (Smokowski et al., 2016; Soomro \& Clarbour, 2012). Physical activity is an area of action which involves achievement motivation similar to the school context. Furthermore, as the Muller, Bushman, Subra, and Ceaux (2012) studies indicate, perceiving oneself as better or worse than a co-contestant appears to be the key factor in presenting aggressive behaviours towards them. Therefore, the relation including the intensiveness (low/high) and the organization of participation (competitive or recreational sports) in physical activity could be a potential factor modifying self-esteem and as a result aggressiveness.

For this reason, the goal of this work is to analyse levels of aggressiveness and self-esteem in relation to levels of physical activity. The following hypotheses were made:

Hypothesis 1: Teenagers who do not engage in physical activity are characterised by higher levels of aggression in comparison to individuals who do engage in physical activity.

Hypothesis 2: Individuals who do sports are characterised by higher levels of self-esteem in comparison to individuals who are physically inactive, those who only partake in physical education (PE) classes, and those who engage in additional self-organised physical activity.

Hypothesis 3: The relationship between physical activity and aggressiveness is mediated by self-esteem.

\section{PARTICIPANTS AND PROCEDURE}

\section{PARTICIPANTS}

A total of 968 adolescents from Pomerania in Poland took part in the study. They were purposively selected from an age cohort $\left(M_{\text {age }}=15.96, S D=0.30\right)$ of individuals with varying levels of physical activity (PA). Participants were divided into four subgroups according to their declaration in the Inventory of Physical Activity Objectives (IPAO; Lipowski \& Zaleski, 2015): 1) a non-active group, $n=141$ (95 girls) - teenagers who are exempt from PA classes and did not report taking part in self-organised PA; 2) a PE group, $n=514$ (322 girls) - teenagers who only do PA in school (physical education class); 3) a high PA group, $n=178$ (81 girls) - teenagers who participate in PE classes and are also physically active (PA) by themselves (not involved in any organized forms of $\mathrm{PA}$ ), engaging in physical activity for at least $60 \mathrm{~min}$, 4 to 7 days a week (hours a week devoted to training: $M=10.69, S D=5.78)$; and 4 ) an athlete group, $n=135$ (66 girls) - teenagers who train regularly (hours a week devoted to training: $M=14.07, S D=5.16$ ), have valid club licences, and represent clubs in country-level competitions. The athlete group included individuals who train individual sports (sport gymnastics, swimming, track-and-field), team sports (basketball, soccer, volleyball, handball), martial arts (fencing, judo), and aesthetic disciplines (dance, artistic gymnastics).

\section{PROCEDURE}

Schools were randomly selected (10 of 12 sport schools and 25 of 381 general education schools) from the Pomeranian Office of Education database. Complete data were obtained from $35 \%$ of students from general schools and $45 \%$ of students from sport schools.

All participants and their parents gave informed consent to participate in the study and were informed that they could discontinue their participation at any time. The study was approved by the Ethics Board for Research Projects at the Institute of Psychology, University of Gdansk, Poland (decision no. 4/2014).

\section{MEASURES}

Participants were asked to complete a sociodemographic survey and a set of questionnaires.

The Inventory of Physical Activity Objectives (IPAO) by Lipowski and Zaleski (2015) was used to determine the level of involvement in PA. We used only part of the inventory that allows one to analyse the extent of engaging in physical activity. Questions regard respondents' involvement in competitive sports (both present and prior) and the forms and intensity of their physical activity (number of hours devoted to doing team and individual sports, using the gym, or fitness classes). Respondents also answered questions regarding regular engagement in PE classes and whether they have a doctor's note for long-term exemption from such classes. Taking part in physical activity in one's free time - both organised and unorganized - was also analysed, as well as participants' declarations about amount of PA in the past month. This allowed the weekly number of hours spent on PA to be analysed.

The Adolescent Aggressiveness Questionnaire Emotional Reactivity (KAM-RE; Sajewicz-Radtke, Radtke, \& Kalka, 2010) was used for the evaluation of aggressiveness in adolescents. KAM-RE measures the level of aggression in children and adolescents
Physical activity and individual differences 
Magdalena Jochimek, Ariadna Beata Łada aged 13-16. This questionnaire is a self-report measure, consisting of 60 items, to which participants respond on a 5-point Likert scale $(1$ - definitely not, 3 - I don't know, 5 - definitely yes), indicating how much a given statement applies to their behaviour. It contains 5 subscales: Direct aggression, Indirect aggression, Emotional irritability, Opposition, and Verbal aggression (Sajewicz-Radtke et al., 2010). Direct aggression refers to the use of physical force against other people, to cause harm when the other person or group of people is motivated to avoid it. Another scale, Indirect aggression, concerns behaviours aimed at harming other people, excluding physical violence; it also includes indirect aggressive behaviours (such as bursts of anger, stamping legs, malicious jokes, and gossip). Emotional irritability is elicited by a tendency to manifest negative emotions at the slightest provocation from others. Opposition refers to any behaviour directed against authority, including both opposition and the fight against applicable standards, norms, and customs. The last subscale, Verbal aggression, is associated with the expression of negative feelings both in form and in content of verbal expressions (screaming, curses). The result of the questionnaire is the total amount of points obtained on every subscale; moreover, it is possible to calculate the level of aggression for each of the subscales. The higher the score, the higher the level of aggression. The external validity of the KAM-RE scale was analysed by correlating it with Buss and Durke's Aggression Scale questionnaire subscales: correlations were found to be high (between .61 and .79 for the respective subscales in both questionnaires); the test-retest reliability for the KAM-RE subscales was between .80 and .87 and was .90 for the overall score (Sajewicz-Radtke et al., 2010). It should be added that Cronbach's $\alpha$ values in this study were as follows: .86 for direct aggression, .86 for indirect aggression, .73 for emotional irritability, .79 for opposition, and .85 for verbal aggression. The reliability (Cronbach's $\alpha$ ) for general aggression level was .94.

The Rosenberg Self-Esteem Scale (SES; Rosenberg, 1965; The Morris Rosenberg Foundation, 2006), in the Polish adaptation by Łaguna, Lachowicz-Tabaczek, and Dzwonkowska (2007), was used in order to assess general level of self-esteem. The SES is a short, self-report questionnaire which is used to assess selfesteem and attitudes towards oneself (Dzwonkowska, Lachowicz-Tabaczek, \& Łaguna, 2008; Łaguna et al., 2007; Rosenberg, 1965; The Morris Rosenberg Foundation, 2006). The SES consists of 10 items to which participants respond on a 4-point Likert scale from 1 (I strongly agree) to 4 (I strongly disagree). The sum of points obtained on all the 10 items is the final result of the SES. The range of results is between 10 and 40; the higher the score, the higher the self-esteem. The reliability of the Polish version of the SES for the youth group, measured using Cronbach's $\alpha$, was high: .81. In the adaptation by Dzwonkowska et al. (2008), factor analysis allowed the identification of one scale in the questionnaire. The SES has positive relationships with questionnaires measuring emotional dispositions, characteristics indicating readiness for action, and variables associated with goal-oriented and social functioning (Dzwonkowska et al., 2008). In this study, Cronbach's $\alpha$ coefficient for SES results was 60 .

\section{STATISTICAL ANALYSIS}

Statistical analysis was conducted in Statistical Package for the Social Sciences (SPSS) version 25 (SPSS Inc., license purchased by University of Gdansk), using: factor structure analysis of variance (ANOVA) with post-hoc analysis (Tukey's Test Unequal N HSD), Pearson's $r$ correlation and mediation analysis.

\section{RESULTS}

First, mean scores for aggressiveness and its subscales, self-esteem, weekly engagement in activities other than physical activity, and monthly number of days participants skipped school were calculated for every group of participants. After calculating the normalised sten scores, it was found that the analysed groups had average scores for aggressiveness $(M=5.33$, $S D=1.96)$ and self-esteem $(M=5.05, S D=2.35)$.

Then an ANOVA (2: gender $\times$ 4: PA level) was performed, which found statistically significant gender or physical-activity-related differences in order to verify the first and the second hypotheses. Posthoc analysis with Tukey's HSD adjustment revealed significant intergroup differences in levels of aggressiveness and self-esteem (Table 1).

A main effect of gender on Emotional irritability was documented $(p<.001)$, where girls scored significantly higher than boys. In turn, boys scored higher than girls in terms of Direct aggression $(p<.001)$, Indirect aggression $(p<.001)$, and Self-esteem $(p<.001)$.

A main effect of level of PA was also observed. The non-active group scored higher than the PE $(p=.001)$ and high-intensity PA $(p=.019)$ groups on the general aggressiveness scale. Moreover, the non-active group scored higher on Direct aggression than the PE group $(p=.016)$. On the Indirect aggression scale, the non-active group scored higher than the PE group $(p=.001)$ and the athlete group had higher scores than the PE group $(p=.035)$. In the case of the Opposition scale, the non-active group scored higher than the PE group $(p=.001)$ and the high PA group $(p=.021)$. Moreover, on the Verbal aggression scale, the non-active group scored higher than the PE group $(p=.005)$ and the high PA group $(p=.005)$. One difference was found for self-esteem: the high PA group scored higher than the non-active group $(p=.016)$. 


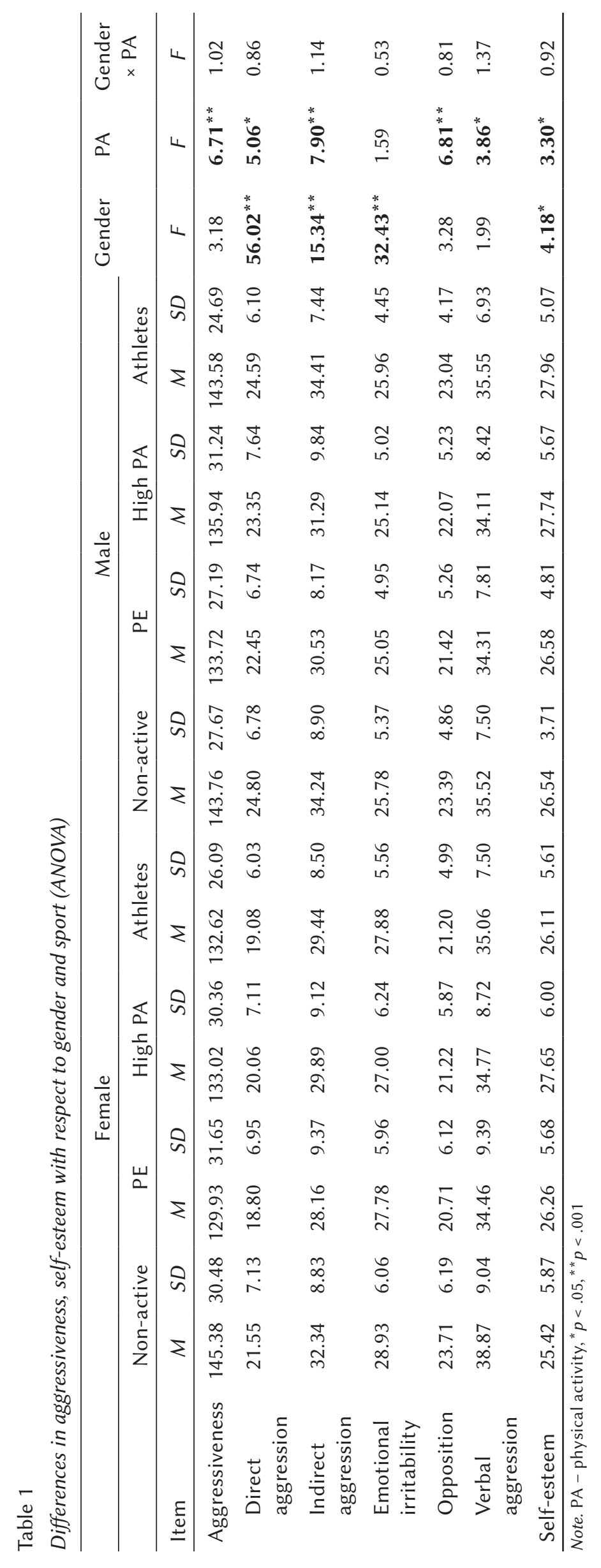

Physical activity and individual differences 
No gender $\mathrm{x}$ sport effect was observed for the analysed dimensions.

To test hypothesis 3 , that physical activity influence aggressiveness, and self-esteem will mediate the above relation, mediation analyses were conducted. Based on the PROCESS bootstrapping macro (Hayes, 2013), we included physical activity as the predictor, adolescents' self-esteem as the hypothesized mediator, and general aggression and its dimensions (direct aggression, indirect aggression, emotional irritability, opposition, and verbal aggression) as the dependent variables. The gender effect was controlled in the above analysis. The results indicated that effects of physical activity on aggressiveness and its dimensions, through the mediation effect of self-esteem, were insignificant for all levels of physical activity and also for the non-active group.

\section{DISCUSSION}

Gender differences were observed in the aggression dimensions: girls were characterised by higher emotional irritability and boys by higher direct and indirect aggression. This means that girls have a higher tendency to react with anger and negative emotions to situations perceived as a provocation or failure; similar results were observed by Caprara, Paciello, Gerbino, and Cugini (2007). Boys, in turn, respond to frustration with physical force, jeering, or emotional reactions to a higher degree (Sajewicz-Radtke et al., 2010). Research by Kumari, Kang, and Princy (2014) found boys to be more negative, verbally aggressive, and assaultive in comparison to girls. However, in that research project, levels of aggressiveness were measured using a different questionnaire.

The non-active group scored higher on most of the aggression subscales as well as on overall score, in comparison to the PE group and the high PA group, but no statistically significant differences were observed in comparison to the group engaging in sports; thus, the first hypothesis can be only partially accepted. Research suggests that taking part in obligatory physical education classes is beneficial for the development of emotion regulation skills and behaviour. It ought to be added that participation in this school class does not meet WHO recommendations regarding the amounts of physical activity per day (Start Active Stay Active, 2011). In the context of the analysed variables associated with the levels of aggression, 4 hours of obligatory PE classes seems to be the minimum amount of physical activity for fostering constructive management of frustrating situations and provocation. Physical activity at school (PE classes and sports) plays an important role in supporting continued physical activity throughout the rest of one's life, as well as development of social skills and social behaviours and pro-school attitudes
(Bailey, 2006). Research regarding the relationship between intense physical activity and aggressive behaviours is scarce. A study from the Czech Republic showed that vigorous physical activity fosters positive developmental changes, but it is also associated with higher probability of engagement in frequent fighting (Hamrrík et al., 2015).

It should be stressed that the athlete group did not differ from the physically inactive teenagers in terms of levels of aggression. Research by Szmajke (1993) indicates that, in boys, partaking in sports can increase the tendencies associated with lesser need for social approval and pursuing standards of masculinity associated with aggressiveness, which are characteristic of adolescence. However, our research did not reveal differences between adolescent male and female athletes, which is why these interpretations should be considered with caution. Previous research has shown that taking part in sports protects one from engaging in problematic behaviours, however in the case of aggression, male athletes scored higher than male non-athletes, while female athletes scored lower than female non-athletes (Rhea \& Lantz, 2004). In turn, a meta-analysis by Sønderlund et al. (2014) suggests that athletes are characterised by higher indices of violence than non-athletes. For this reason it is also worth noting the study by Fung and Lee (2018) which found that doing sports only reduces aggression if it is accompanied by studying Chinese martial arts and moral philosophy.

It is interesting that individuals who practise sports are characterised by higher levels of indirect aggression than are individuals who take part in physical education. For this reason, it is worth engaging in further, more detailed analyses of this phenomenon in the group of individuals who train sports, as well as in the context of their ways of perceiving rivalry and rules associated with rivalry during sport competitions. Direct expressions of anger and behaviours indicating high levels of direct or verbal aggression in a sports situation are regulated by disciplinary penalties. Thus, indirect aggression may be a more desirable strategy for expressing anger.

The mean score of the studied teenagers on the self-esteem scale is lower than the one in the normalisation sample (Dzwonkowska et al., 2008). It is worth noting the age difference between the participants of the current study and the participants of the cited study, which was between 14 and 18 significant changes in self-esteem may occur during puberty (Kort-Butler \& Hagewen, 2011). Moreover, as in the study by Dzwonkowska et al. (2008), mean scores in our study indicate average levels of this personality feature. In our study, boys were characterised by higher self-esteem than girls; similarly, the group engaging in intensive physical activity had higher self-esteem than the physically inactive group. Research by Viira (2011) indicates that 
boys are characterised by higher self-assessment of their physicality and higher stability in time thereof, which may partially explain our results. Interestingly, no differences were observed in self-esteem between groups taking part in organised physical activity (PE and athletes) in comparison to non-active individuals, which is why the second hypothesis should be rejected. The data are even more interesting in the context of the finding of Nelson and Gordon-Larsen (2006) that physically active teenagers are less likely to have low self-esteem. Additionally, assessment of one's skills was associated with global self-esteem and partaking in sports gives one the opportunity for self-improvement and to prove oneself in training and competing. Moreover, research indicates that it is possible to strengthen teenagers' self-concept and self-esteem through physical activity, especially when it is an isolated intervention (not combined with developing other skills) and is directed at teenagers in a school environment (Liu, Wu, \& Ming, 2015). The higher the levels of physical activity an individual has, the better their perception of their physical self, especially their sporting competence and physical condition (Niven, Fawkner, Knowles, \& Stephenson, 2007). Gender is a moderator of this relationship - the correlation is stronger in boys (Babic et al., 2014). However a longitudinal study showed that both sport proficiency and physical condition are cross-sectional and longitudinal indicators of physical activity and other behaviours related to health as well as low levels of anxiety related to others' assessments of one's looks in both boys and girls (Crocker, Sabiston, Kowalski, McDonough, \& Kowalski, 2006). Body image was inversely correlated with physical activity. It is worth adding that physical self-perception is both the effect of physical activity and its determinant. Thus, a positive feedback loop may be observed in the mutual influences of these two variables. Neumark-Sztainer, Paxton, Hannan, Haines, and Story (2006) recommend the development of a sense of acceptance of one's own body among teenagers, because dissatisfaction with one's looks is to a large degree correlated with behaviours that do not benefit one's health.

The analyses showed that global levels of selfesteem do not mediate the relationship between physical activity and aggression in youth, which is why the third hypothesis should be rejected. A study by Martínez-Martínez et al. (2018) showed that relational and overt aggressiveness are related to selfesteem and physical activity. However, aggression and physical activity in this study were analysed using a different theoretical construct. It should also be added that self-esteem is important for teenagers' development of identity and peer aggression, and low levels of self-esteem can lead to internalisation problems in individuals who exhibit aggressive behaviours (Ybrandt \& Armelius, 2010). Thus, it may be that self-esteem influences levels of aggressiveness in situations where it is problematic, which is why no such relationship was observed in our study.

\section{LIMITATIONS}

The main limitation of the present study was its explorative character and associated issues with unequal groups and the measurement tools used. Participants answered questions regarding the way they perceive their self-esteem and their aggressive behaviours as well as the number of hours devoted to particular types of physical activity. Using tools which collect data regarding actual physical activity, e.g. an accelerometer, would make it possible to objectively analyse both engagement in physical activity and sedentary behaviours (e.g. associated with preparing for school or watching TV series). The declarative and subjective perceptions of aggression may also bias results regarding aggressive behaviours. For this reason, future studies should take into account how teenagers' behaviours are perceived by their parents, teachers, or coaches. Such triangulation of data could allow more objective inferences to be made about actual levels of aggression.

Moreover, in future studies, selecting a different tool for measuring self-esteem should be considered, especially if one of the co-variables is to be the level of physical activity. On one hand, specific assessments of one's abilities are associated with global levels of self-esteem, and self-esteem regarding one's physical aspects influences the overall levels of selfesteem (Bowker, 2006; Guszkowska et al., 2015). On the other hand, using a tool that measures self-esteem multidimensionally could allow analysis of the role of separate components of self-esteem in detail, not only in relation to physical activity, but also ways of spending one's free time and aggression levels.

Finally, in the future research, the number of participants representing various levels of physical activity should be increased. It will eliminate the problem with a potential impact of group size on the research results.

\section{CONCLUSIONS}

In summary, we observed gender differences and differences associated with physical activity levels in levels of aggression and its dimensions and self-esteem. However, no interaction effects were observed for levels of physical activity and gender. Undertaking compulsory physical activity in school and additional physical activity based on one's own interests is associated with lower levels of aggression in comparison to individuals who do not undertake any physical activity. For this reason, it is necessary to
Physical activity and individual differences 
continue consistently promoting physical activity in school and during free time. Prophylactic interventions should also be directed at adolescents' parents; the content of these interventions should concern issues related to both physical and emotional health.

\section{FUNDING}

This study was supported by the Faculty of Tour-

Magdalena Jochimek, Ariadna Beata Łada

\section{References}

Allen, J. P., Porter, M. R., \& McFarland, F. C. (2006) Leaders and followers in adolescent close friendships: Susceptibility to peer influence as a predictor of risky behavior, friendship instability, and depression. Development and Psychopathology, 18, 155172. https://doi.org/10.1017/S0954579406060093

Arnold, M. E. (2017). Supporting adolescent exploration and commitment: identity formation, thriving, and positive youth development. Journal of Youth Development, 12, 1-15. https://doi.org/10.5195/ jyd.2017.522

Babic, M. J., Morgan, P. J., Plotnikoff, R. C., Lonsdale, C., White, R. L., \& Lubans, D. R. (2014). Physical activity and physical self-concept in youth: systematic review and meta-analysis. Sports Medicine, 44, 1589-1601. https://doi.org/10.1007/s40279014-0229-z

Bailey, R. (2006). Physical education and sport in schools: a review of benefits and outcomes. The Journal of School Health, 76, 397-401. https://doi. org/10.1111/j.1746-1561.2006.00132.x

Bernacka, K., \& Tokarz, A. (2012). Nastrój i samoocena jako czynniki psychologiczne związane w wynikiem w piłce siatkowej [Mood and self-esteem as psychological factors associated with results in volleyball]. In J. Blecharz, M. Siekańska, \& A. Tokarz (Eds.), Optymalizacja treningu sportowego i zdrowotnego z perspektywy psychologii [Psychological aspects of coaching in sport psychology] (pp. 123138). Cracow: Wydawnictwo AWF w Krakowie.

Bernstein, E. E., \& McNally, R. J. (2017). Acute aerobic exercise helps overcome emotion regulation deficits. Cognition and Emotion, 31, 834-843. https:// doi.org/10.1080/02699931.2016.1168284

Boden, J. M., Fergusson, D. M., \& Horwood, L. J. (2007). Self-esteem and violence: Testing links between adolescent self-esteem and later hostility and violent behavior. Social Psychiatry and Psychiatric Epidemiology, 42, 881-891. https://doi. org/10.1007/s00127-007-0251-7
Bowker, A. (2006). The relationship between sports participation and self-esteem during early adolescence. Canadian Journal of Behavioural Science / Revue canadienne des sciences du comportement, 38, 214-229. https://doi.org/10.1037/cjbs2006009

Brinthaupt, T. M., \& Lipka, R. P. (2002). Understanding early adolescent self and identity: applications and interventions. Albany: State University of New York Press.

Brown, B. B. (2004). Adolescents' relationships with peers. In R. M. Lerner \& L. Steinberg (Eds.), Handbook of adolescent psychology (2 ${ }^{\text {nd }}$ ed.) (pp. 363394). Hoboken, NJ: John Wiley \& Sons Inc.

Budnik, D., \& Kaźmierczak, M. (2008). Sport w życiu współczesnych nastolatków [Sport in the lives of current day teenagers]. In M. Krawczyński (Ed.), Psychologiczne konteksty aktywności fizycznej człowieka [Psychological contexts of human physical activity] (pp. 185-198). Gdańsk: Szkoła Wyższa Ateneum.

Bushman, B. J., Baumeister, R. F., Thomaes, S., Ryu, E., Begeer, S., \& West, S. G. (2009). Looking again, and harder, for a link between low self-esteem and aggression. Journal of Personality, 77, 427-446. https://doi.org/10.1111/j.1467-6494.2008.00553.x

Caprara, G. V., Paciello, M., Gerbino, M., \& Cugini, C. (2007). Individual differences conducive to aggression and violence: trajectories and correlates of irritability and hostile rumination through adolescence. Aggressive Behavior, 33, 359-374. https:// doi.org/10.1002/ab.20192

Carraro, A., Gobbi, E., \& Moè, A. (2014). Brief report: play fighting to curb self-reported aggression in young adolescents. Journal of Adolescence, 37, 1303-1307. https://doi.org/10.1016/j.adolescence.2014.09.009

Carson, V., Staiano, A. E., \& Katzmarzyk, P. T. (2015). Physical activity, screen time, and sitting among U.S. adolescents. Pediatric Exercise Science, 27, 151-159. https://doi.org/10.1123/pes.2014-0022

Chen, A. (2012). Exercise facilitates memory: Implications for helping youngsters learn in school. Journal of Sport and Health Science, 1, 5-6. https://doi. org/10.1016/j.jshs.2012.04.003

Collins, W. A., \& Steinberg, L. (2006). Adolescent development in interpersonal context. In N. Eisenberg, W. Damon, \& R. M. Lerner (Eds.), Handbook of child psychology: Social, emotional, and personality development (vol. 3, $6^{\text {th }}$ ed.) (pp. 1003-1067). Hoboken, NJ: John Wiley \& Sons Inc.

Cook, T. D., Deng, Y., \& Morgano, E. (2007). Friendship influences during early adolescence: the special role of friends' grade point average. Journal of Research on Adolescence, 17, 325-356. https://doi. org/10.1111/j.1532-7795.2007.00525.x

Costin, S. E., \& Jones, D. C. (1992). Friendship as a facilitator of emotional responsiveness and prosocial interventions among young children. Developmental Psychology, 28, 941-947. https://doi.org/ 10.1037/0012-1649.28.5.941 
Crocker, P. R. E., Sabiston, C. M., Kowalski, K. C., McDonough, M. H., \& Kowalski, N. (2006). Longitudinal assessment of the relationship between physical self-concept and health-related behavior and emotion in adolescent girls. Journal of $\mathrm{Ap}$ plied Sport Psychology, 18, 185-200. https://doi. org/10.1080/10413200600830257

Dzwonkowska, I., Lachowicz-Tabaczek, K., \& Łaguna, M. (2008). Samoocena i jej pomiar. Polska adaptacja skali SES M. Rosenberga [Self-esteem and its measurement. Polish adaptation of the SES scale]. Warsaw: Pracownia Testów Psychologicznych.

Erikson, E. H. (1968). Identity, youth, \& crisis. New York: Norton.

Ersing, R. L. (2009). Building the capacity of youths through community cultural arts. Best Practices in Mental Health, 5, 26-43.

Farrell, A. D., Thompson, E. L., \& Mehari, K. R. (2018). "Dimensions of peer influences and their relationship to adolescents' aggression, other problem behaviors and prosocial behavior": Correction. Journal of Youth and Adolescence, 47, 243-243. https:// doi.org/10.1007/s10964-017-0788-z

Fung, A. L. C., \& Lee, T. K. H. (2018). Effectiveness of Chinese martial arts and philosophy to reduce reactive and proactive aggression in schoolchildren. Journal of Developmental and Behavioral Pediatrics, 39, 404414. https://doi.org/10.1097/DBP.0000000000000565

Graber, J. A., Brooks-Gunn, J., \& Warren, M. P. (2006). Pubertal effects on adjustment in girls: moving from demonstrating effects to identifying pathways. Journal of Youth and Adolescence, 35, 413423. https://doi.org/10.1007/s10964-006-9049-2

Guszkowska, M., Kuk, A., Zagórska, A., \& Skwarek, K. (2015). Self-esteem of physical education students: sex differences and relationships with intelligence. Current Issues in Personality Psychology, 4, 50-57. https://doi.org/10.5114/cipp.2015.55406

Hagger, M. S., Biddle, S. J. H., \& Wang, C. K. J. (2005). Physical self-concept in adolescence: generalizability of a multidimensional, hierarchical model across gender and grade. Educational and Psychological Measurement, 65, 297-322. https://doi. org/10.1177/0013164404272484

Hamřík, Z., Bobáková, D., Kalman, M., Veselská, Z. D., Klein, D., \& Gecková, A. M. (2015). Physical activity and screen-based activity in healthy development of school-aged children. Central European Journal of Public Health, 23, 50-56. https://doi. org/10.21101/cejph.a4188

Harter, S. (2012). The construction of the self: developmental and sociocultural foundations ( $2^{\text {nd }}$ ed.). New York, NY: Guilford Press.

Hayes, A. F. (2013). Introduction to Mediation, Moderation, and Conditional Process Analysis: A RegressionBased Approach. New York, NY: The Guilford Press.

Howie, E. K., \& Pate, R. R. (2012). Physical activity and academic achievement in children: a historical perspective. Journal of Sport and Health Science, 1, 160-169. https://doi.org/10.1016/j.jshs.2012.09.003

Hrafnkelsdottir, S. M., Brychta, R. J., Rognvaldsdottir, V., Gestsdottir, S., Chen, K. Y., Johannsson, E., Guðmundsdottir, S. L. \& Arngrimsson, S. A. (2018). Less screen time and more frequent vigorous physical activity is associated with lower risk of reporting negative mental health symptoms among Icelandic adolescents. PLoS One, 13, 1-15. https://doi. org/10.1371/journal.pone.0196286

Isasi, C. R., Ostrovsky, N. W., \& Wills, T. A. (2013). The association of emotion regulation with lifestyle behaviors in inner-city adolescents. Eating $\mathrm{Be}$ haviors, 14, 518-521. https://doi.org/10.1016/j.eatbeh.2013.07.009

Jones, J. N., \& Deutsch, N. L. (2012). Social and identity development in an after-school program: changing experiences and shifting adolescent needs. The Journal of Early Adolescence, 33, 17-43. https://doi.org/10.1177/0272431612462628

Kann, L., McManus, T., Harris, W. A., Shanklin, S. L., Flint, K. H., Hawkins, J., Queen, B., Lowry, R., Olsen, E. O., Chyen, D., Whittle, L., Thornton, J., Lim, C., Yamakawa, Y., Brener, N., \& Zaza, S. (2016). Youth risk behavior surveillance - United States, 2015. Morbidity and Mortality Weekly Report. Surveillance Summaries (Washington, D.C.: 2002), 65, 1-174. https://doi.org/10.15585/mmwr.ss6506a1

Kołoło, H., Guszkowska, M., Mazur, J., \& Dzielska, A. (2018). Self-efficacy, self-esteem and body image as psychological determinants of 15-year-old adolescents' physical activity levels. Human Movement, 13, 264-270. https://doi.org/10.2478/v10038012-0031-4

Kort-Butler, L. A., \& Hagewen, K. J. (2011). Schoolbased extracurricular activity involvement and adolescent self-esteem: a growth-curve analysis. Journal of Youth and Adolescence, 40, 568-581. https://doi.org/10.1007/s10964-010-9551-4

Kumari, V., Kang, T. K., \& Princy (2014). Aggression among adolescents across different socio-economic developmental strata: a comparative study. Indian Journal of Health \& Wellbeing, 5, 1194-1197.

Kuntsche, E., Simons-Morton, B., Fotiou, A., ter Bogt, T., Kokkevi, A., \& Health Behavior in School-Aged Children Study (2009). Decrease in adolescent cannabis use from 2002 to 2006 and links to evenings out with friends in 31 European and North American countries and regions. Archives of Pediatrics \& Adolescent Medicine, 163, 119-125. https://doi.org/10.1001/archpediatrics.2008.542

Larson, R. W., Hansen, D. M., \& Moneta, G. (2006). Differing profiles of developmental experiences across types of organized youth activities. Developmental Psychology, 42, 849-863. https://doi.org/ 10.1037/0012-1649.42.5.849

Lickley, R. A., \& Sebastian, C. L. (2018). The neural basis of reactive aggression and its development in
Physical activity and individual differences 
adolescence. Psychology, Crime \& Law, 24, 313-333. https://doi.org/10.1080/1068316X.2017.1420187

Lipowski, M., \& Zaleski, Z. (2015). Inventory of Physical Activity Objectives - a new method of measuring motives for physical activity and sport. Health Psychology Report, 3, 47-58. https://doi.org/10.5114/ hpr.2015.49462

Lippold, M. A., Hussong, A., Fosco, G. M., \& Ram, N. (2018). Lability in the parent's hostility and warmth toward their adolescent: linkages to youth
Magdalena Jochimek, Ariadna Beata Łada delinquency and substance use. Developmental Psychology, 54, 348-361. https://doi.org/10.1037/ dev0000415

Liu, M., Wu, L., \& Ming, Q. (2015). How does physical activity intervention improve self-esteem and selfconcept in children and adolescents? Evidence from a meta-analysis. PLoS One, 10, e0134804. https://doi.org/10.1371/journal.pone.0134804

Łaguna, M., Lachowicz-Tabaczek, K., \& Dzwonkowska, I. (2007). Skala samooceny SES Morrisa Rosenberga - polska adaptacja metody [Morris Rosenberg's SES scale of self-esteem - Polish adaptation of the method]. Psychologia Spoteczna, 2, 164-176.

Martínez-Martínez, A., Castro-Sánchez, M., RodríguezFernández, S., Zurita-Ortega, F., Chacón-Cuberos, R., \& Espejo-Garcés, T. (2018). Violent behaviour, victimization, self-esteem and physical activity of Spanish adolescents according to place of residence: A structural equation model. Revista de Psicología Social, 33, 111-141. https://doi.org/10.1080/0 2134748.2017.1385242

McMullen, J., Ni Chróinín, D., Tammelin, T., Pogorzelska, M., \& van der Mars, H. (2015). International approaches to whole-of-school physical activity promotion. Quest, 67, 384-399. https://doi.org/10. 1080/00336297.2015.1082920

Moreno, C., Sánchez-Queija, I., Muñoz-Tinoco, V., de Matos, M. G., Dallago, L., Bogt, T. T., Camacho, I., Rivera, F., \& HBSC Peer Culture Focus Group (2009). Cross-national associations between parent and peer communication and psychological complaints. International Journal of Public Health, 54, 235-242. https://doi.org/10.1007/s00038-009-5415-7

Muller, D., Bushman, B. J., Subra, B., \& Ceaux, E. (2012). Are people more aggressive when they are worse off or better off than others? Social Psychological and Personality Science, 3, 754-759. https:// doi.org/10.1177/1948550612436984

Nelson, M. C., \& Gordon-Larsen, P. (2006). Physical activity and sedentary behavior patterns are associated with selected adolescent health risk behaviors. Pediatrics, 117, 1281-1290. https://doi. org/10.1542/peds.2005-1692

Neumark-Sztainer, D., Paxton, S. J., Hannan, P. J., Haines, J., \& Story, M. (2006). Does body satisfaction matter? Five-year longitudinal associations between body satisfaction and health behaviors in adolescent females and males. Journal of Adoles- cent Health, 39, 244-251. https://doi.org/10.1016/j. jadohealth.2005.12.001

Niven, A. G., Fawkner, S. G., Knowles, A. M., \& Stephenson, C. (2007). Maturational differences in physical self-perceptions and the relationship with physical activity in early adolescent girls. Pediatric Exercise Science, 19, 472-480. https://doi. org/10.1123/pes.19.4.472

Oosterhoff, B., Kaplow, J. B., Wray-Lake, L., \& Gallagher, K. (2017). Activity-specific pathways among duration of organized activity involvement, social support, and adolescent well-being: findings from a nationally representative sample. Journal of Adolescence, 60, 83-93. https://doi. org/10.1016/j.adolescence.2017.07.012

Osgood, D. W., Ragan, D. T., Wallace, L., Gest, S. D., Feinberg, M. E., \& Moody, J. (2013). Peers and the emergence of alcohol use: influence and selection processes in adolescent friendship networks. Journal of Research on Adolescence, 23, 500-512. https://doi.org/10.1111/jora.12059

Owczarek, A. (2009). Obraz siebie i samoocena sportowców wysoko kwalifikowanych [Self-image and self-esteem of highly qualified athletes]. In J. Blecharz \& M. Siekańska (Eds.), Praktyczna psychologia sportu: wykorzystanie koncepcji psychologicznych w sporcie [Practical sports psychology: the use of psychological concepts in sport] (pp. 196207). Cracow: Wydawnictwo AWF w Krakowie.

Park, S., Chiu, W., \& Won, D. (2017). Effects of physical education, extracurricular sports activities, and leisure satisfaction on adolescent aggressive behavior: a latent growth modeling approach. PLoS One, 12, 1-13. https://doi.org/10.1371/journal.pone. 0174674

Petersen, A. C., \& Leffert, N. (1995). What is special about adolescence? In M. Rutter (Ed.), Psychosocial disturbances in young people: Challenges for prevention. (pp. 3-36). New York, NY: Cambridge University Press.

Poitras, V., Gray, C., Borghese, M., Carson, V., Chaput, J. P., Janssen, I., Katzmarzyk, P. T., Pate, R. R, Connor Gorber, S., Kho, M. E., Sampson, M., \& Tremblay, M. S. (2016). Systematic review of the relationships between objectively measured physical activity and health indicators in school-aged children and youth. Applied Physiology, Nutrition, and Metabolism, 41, 197-239. https://doi.org/10.1139/ apnm-2015-0663

Ragelienè, T. (2016). Links of adolescents identity development and relationship with peers: a systematic literature review. Journal of the Canadian Academy of Child \& Adolescent Psychiatry, 25, 97-105.

Reardon, K. W., Herzhoff, K., \& Tackett, J. L. (2016). Adolescent personality as risk and resiliency in the testosterone-externalizing association. Journal of Research on Adolescence, 26, 390-402. https://doi. org/10.1111/jora. 12198 
Rhea, D. J., \& Lantz, C. D. (2004). Violent, delinquent, and aggressive behaviors of rural high school athletes and non-athletes. Physical Educator, 61, 170-176.

Rosenberg, M. (1965). Society and the adolescent selfimage. New Jersey: Princeton University Press.

Rosenberg, M. (1979). Conceiving the self. New York: Basic Books.

Sajewicz-Radtke, U., Radtke, B. M., \& Kalka, D. (2010). Kwestionariusz Agresywności Młodzieży Reaktywność Emocjonalna (KAM-RE) [The Adolscent Aggressiveness Questionnaire - Emotional Reactivity (KAM-RE)]. Gdańsk: Pracownia Testów Psychologicznych i Pedagogicznych.

Shields, M. C., Matt, L. M., \& Coifman, K. G. (2016). Physical activity and negative emotion during peer-rejection: evidence for emotion context sensitivity. Journal of Health Psychology, 21, 2851-2862. https://doi.org/10.1177/1359105315587139

Simons-Morton, B. G., \& Farhat, T. (2010). Recent findings on peer group influences on adolescent smoking. The Journal of Primary Prevention, 31, 191-208. https://doi.org/10.1007/s10935-010-0220-x

Simpson, R. L., Peterson, R. L., \& Smith, C. R. (2010). Critical educational program components for students with emotional and behavioral disorders: science, policy, and practice. Remedial and Special Education, 32, 230-242. https://doi.org/ 10.1177/0741932510361269

Smokowski, P. R., Guo, S., Wu, Q., Evans, C. B. R., Cotter, K. L., \& Bacallao, M. (2016). Evaluating dosage effects for the positive action program: how implementation impacts internalizing symptoms, aggression, school hassles, and self-esteem. American Journal of Orthopsychiatry, 86, 310-322. https://doi.org/10.1037/ort0000167

Soomro, N. H., \& Clarbour, J. (2012). Emotional behaviour and academic achievement in middle school children. Pakistan Journal of Social \& Clinical Psychology, 9, 11-17.

Sønderlund, A. L., O’Brien, K., Kremer, P., Rowland, B., De Groot, F., Staiger, P., Zinkiewicz, L., \& Miller, P. G. (2014). The association between sports participation, alcohol use and aggression and violence: A systematic review. Journal of Science and Medicine in Sport, 17, 2-7. https://doi.org/10.1016/j.jsams.2013.03.011

Start Active Stay Active. (2011). A report on physical activity for health from the four home countries' Chief Medical Officers. United Kingdom: The Department of Health.

Stroth, S., Hille, K., Spitzer, M., \& Reinhardt, R. (2009). Aerobic endurance exercise benefits memory and affect in young adults. Neuropsychological Rehabilitation, 19 , 223-243. https://doi.org/10.1080/09602010802091183

Szmajke, A. (1993). "To niedopuszczalne, ale ja to zrobię". Uprawianie sportu a akceptacja agresji i zachowań nieetycznych u chłopców ["It’s inadmissible but I do it". The relationship of sport involvement with school-boys acceptation of aggression and immoral behavior]. Przegląd Psychologiczny, 36, 503-513.

Tabak, I., Mazur, J., \& Nałęcz, H. (2017). Family and individual predictors and mediators of adolescent physical activity. Health Psychology Report, 5, 333-344. https://doi.org/10.5114/hpr.2017.67522

The Morris Rosenberg Foundation. (2006). The Rosenberg Self Esteem Scale. Retrieved from http://www. bsos.umd.edu/socy/grad/socpsy_rosenberg.html

Viira, R. (2011). Adolescents' physical self-perception as related to moderate-to-vigorous physical activity: a one-year longitudinal study. Acta Kinesiologiae Universitatis Tartuensis, 17, 199-208. https:// doi.org/10.12697/akut.2011.17.17

Wade, L., Smith, J. J., Duncan, M. J., \& Lubans, D. R. (2018). Mediators of aggression in a schoolbased physical activity intervention for low-income adolescent boys. Mental Health and Physical Activity, 14, 39-46. https://doi.org/10.1016/j. mhpa.2017.12.006

Walker, J. S., \& Bright, J. A. (2009) False inflated self-esteem and violence: a systematic review and cognitive model. The Journal of Forensic Psychiatry \& Psychology, 20, 1-32. https://doi. org/10.1080/14789940701656808

Woynarowska, B., Mazur, J., \& Oblacińska, A. (2015). Uczestnictwo uczniów w lekcjach wychowania fizycznego w szkołach w Polsce [Attendance of students in PE classes in Polish schools]. Hygeia Public Health, 50, 183-190.

Ybrandt, H., \& Armelius, K. (2010). Peer aggression and mental health problems self-esteem as a mediator. School Psychology International, 31, 146163. https://doi.org/10.1177/0143034309352267

Zambon, A., Morgan, A., Vereecken, C., Colombini, S., Boyce, W., Mazur, J., Lemma, P., \& Cavallo, F. (2010). The contribution of club participation to adolescent health: evidence from Six countries. Journal of Epidemiology \& Community Health, 64, 89-95. https://doi.org/10.1136/jech.2009.088443
Physical activity and individual differences 